\title{
Thermal insulation coating based on water- based polymer dispersion
}

\author{
Iuliia Panchenko ${ }^{1, *}$, Marina Akulova ${ }^{2}$, and Dmitrii Panchenko ${ }^{1}$ \\ ${ }^{1}$ Tyumen Industrial University, 625000 Tyumen, Russia \\ ${ }^{2}$ Ivanovo State Polytechnic University, 153037 Ivanovo, Russia
}

\begin{abstract}
For Russia, due to its long winter period, improvement of thermal insulation properties of envelope structures by applying thermal insulation paint and varnish coating to its inner surface is considered perspective. Thermal insulation properties of such coatings are provided by adding aluminosilicate microspheres and aluminum pigment to their composition. This study was focused on defining the effect of hollow aluminosilicate microspheres and aluminum pigment on the paint thermal insulation coating based on water-based polymer dispersion and on its optimum filling ratio. The optimum filling ratio was determined using the method of critical pigment volume concentration (CPVC). The optimum filling ratio was found equal to $55 \%$.
\end{abstract}

\section{Introduction}

Heat transmission through building envelope structures can occur in different directions depending on climate conditions of the region. The most relevant issue for countries with hot climate or long summer season is decrease of buildings heat gain caused by solar radiation. This problem is solved by covering the surface of building envelope structures with coatings that can reflect solar radiati0n [1-3].

For Russia, due to its long winter period, improvement of thermal insulation properties of envelope structures by applying thermal insulation paint and varnish coating to its inner surface is considered perspective [4-6]. Such materials represent viscous liquid compositions containing binder, hollow microspheres of various nature, such as polymers, glass, aluminosilicate, and titanium pigment [7-12].

It is economically reasonable to consider the possibility of using hollow alunimosilicate microspheres as filler for paint coatings, for their price is 8 to 10 times lower than that of polymer and glass microspheres. While producing paint pigment compositions, the color of microspheres has special relevance and depends on the ability of microspheres to disperse wave radiation in optical wavelengths. This ability is defined by the surface type, microsphere wall thickness and porosity. Shells of micropheres are light-gray and have a small number of closed pores due to which they provide sufficient transparency and do not change paint color and opacity, which allows saving high-priced pigments [13].

\footnotetext{
* Corresponding author: indyboot@list.ru
} 
Optical values that characterize radiation properties of materials are absorption coefficient $\alpha$ and emissivity coefficient $\varepsilon$ [14]. The most complex task is to obtain coatings with low emissivity coefficient values. Therefore, for a coating to be able to reflect thermal radiation it is required to add to its composition a component with high reflective capacity in IR region - aluminum pigment $[15,16]$.

Traditional aluminum pigments are powders PAP-1 and PAP-2 (aluminum pigment powder). However, such pigments have a number of drawbacks: poor wetting properties, oxidation of aluminum particles, fire and explosion hazards, inhalation toxicity, as well as presence of active aluminum able to interact with water [17]. German company Schlenk and American company Eckart developed the technology for obtaining spherical aluminum pigment particles [18]. Aluminum particles are covered with a transparent silicone dioxide layer, which allows using them for water-based paint compositions. Pigments are produced in the form of ready-to-use pigment pastes. In addition to aluminum pigment and water, such pastes contain admixtures for wetting and dispersion, antifoaming agents and special admixtures to optimize rheological properties.

Use of styrene acrylic dispersions as binder for highly filled compositions is considered reasonable due to their optimum price/quality ratio. The research is aimed to define the effect of hollow aluminosilicate microspheres and aluminum pigment on the paint thermal insulation coating based on water-based polymer dispersion and to find its optimum filling ratio.

\section{Materials and Methods}

Light-gray hollow aluminosilicate microspheres (Ural Ekibastuz class) produced by Inotek company were used during the study. Grain size distribution of microspheres was 75-300 microns, with the mean diameter of 152 microns. The image of a microsphere is given in Figure 1.

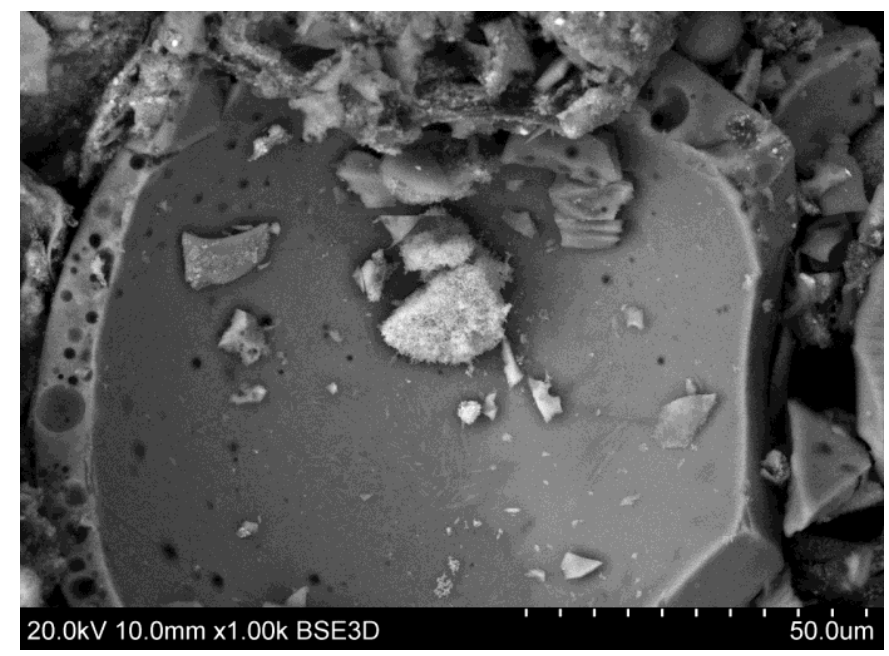

Fig. 1. Micrograph of a hollow aliminosilicate microsphere.

Pigment paste (series Hydroxal DC 5000) produced by Eckart company was used as aluminum pigment. The paste represents water-based dispersion containing $65 \%$ of aluminum pigment with the grain size of 50-70 microns (Fig. 2). 


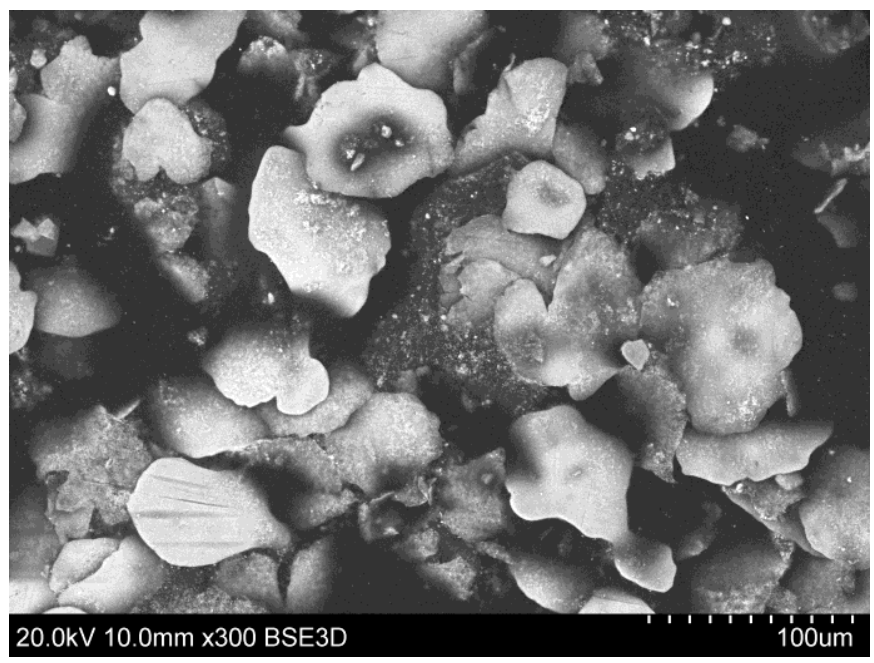

Fig. 2. Micrograph of aluminum pigment.

The task of making a paint formulation consists in selecting composition that provides the paint's stability, good technological properties and forms a film with as closed structure as possible [19]. Pigment concentration at which the filming agent completely covers pigment and filler particles and occupies all space between them is called critical pigment volume concentration (CPVC). As a rule, while increasing the filling ratio of a coating its properties smoothly vary, and at the point of CPVC either sharp variation or almost no further variation of properties occurs [20]. In other words, the best coating properties are obtained when the filling ratio is slightly less than the critical pigment volume concentration. Therefore, CPVC method was used for defining the optimum pigment filling ratio of a paint thermal insulation coating.

\section{Results}

The main characteristics for paint coatings meant for interiors are water absorption of the film, opacity and adhesion to surface. On the one hand, loosening of film-forming agents' structure can be observed in proximity to pigment and filler particles, which can cause degradation of coating properties. And, conversely, when tightened structures of filmformation agent are formed, the coating properties improve [20, 21]. It is known that CPVC of water-based styrene acrylic paints lies between 40 and $80 \%$ [22]. Hence, search of optimum filling ratio was performed in this range. The research results presented in Figures 3-5 show that degradation of coating properties occurs when the CPVC of the film reaches the value of $58 \%$. 


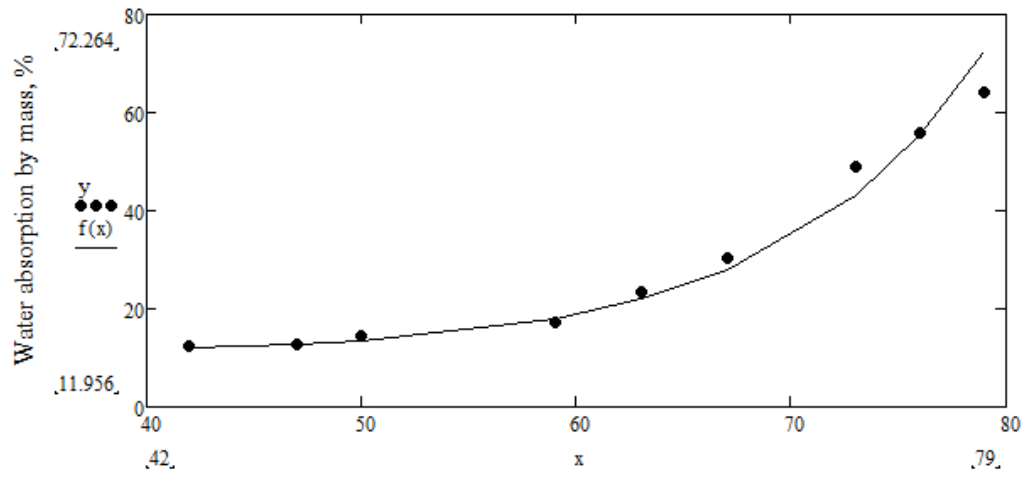

Volumetric concentration of pigment and filler, $\%$

Fig. 3. Dependence of film water absorption on pigment and filler volume concentration. $f(x)=$ $13.975 \cdot 10^{-3} \cdot \exp (0,1062 \cdot \mathrm{x})+10.747$.

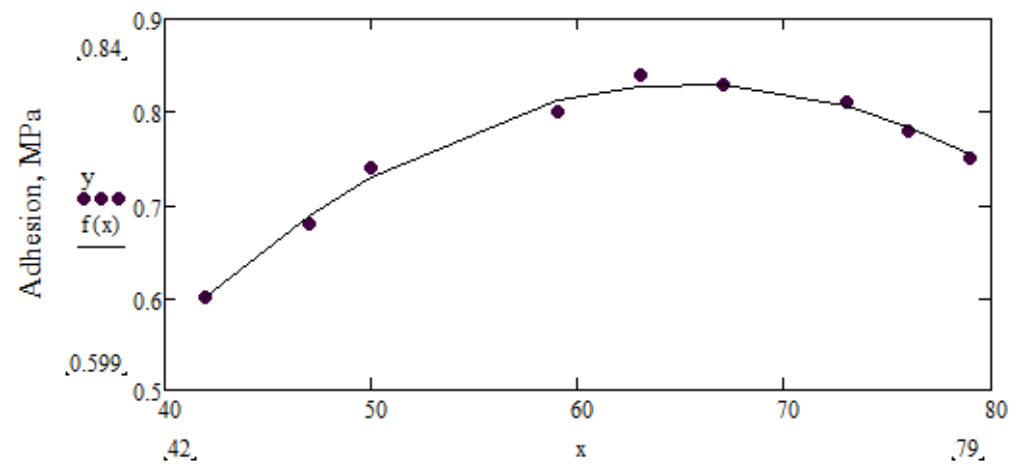

Volumetric concentration of pigment and filler, $\%$

Fig. 4. Dependence of adhesion strength on pigment and filler volume concentration. $f(x)=-$ $0.00042 \cdot x^{2}+0.055 \cdot x-0.97$.

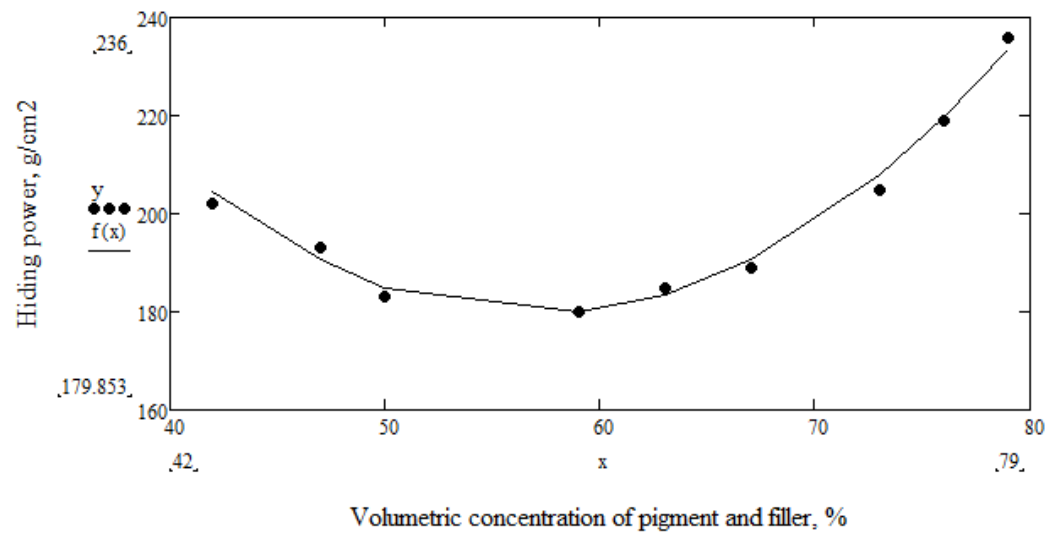

Fig. 5. Dependence of opacity on pigment and filler volume concentration. $f(x)=0.1114 \cdot x^{2}+0.055 \cdot x$ -541.37 . 


\section{Conclusion}

The conducted research proved the ability to obtain thermal insulation paint coating on the basis of styrene acrylic dispersion, aluminosilicate microspheres and aluminum pigment paste. It is found that CPVC of the thermal insulation coating film is $58 \%$. The optimum filling ratio of the coating is proved to be always slightly lower than the CPVC and is $55 \%$.

\section{References}

1. Y. Zhang, E. Long, Y. Li, P. Li, Energy Exploration \& Exploitation, 1-19 (2017)

2. K. Banionis, E. Monstvilas, V. Stankevičius, R. Bliūdžius, K. Miškini, Journal of Civil Engineering and Management, 18, 4 (2012)

3. M. Zinzi, G. Fasano, International Journal of Sustainable Energy, 28, 1-3 (2009)

4. A.N. Trofimov, A.F. Kosolapov, Mezhotraslevoj al'manah, 48 (2014) (in Russian)

5. Y.Y. Kochetova, Bulletin USPTU. Science, Education, Economy. Series Economy, 1(7) (2014) (in Russian)

6. N.N. Zhdanov, R.M. Garipov, A.I. Khasanov, Herald of Kazan Technological University, 16(17) (2014) (in Russian)

7. L. Chen, Journal of Dispersion Science and Technology, 32, 9 (2011)

8. V.S. Belyaev, Patent no. 2304156, Russian Federation (2007)

9. E.B. Bryantcev, Patent no. 2318782, Russian Federation (2008)

10. R.H. Fathutdinov, V.A. Maslov, S.A. Hafizova, Patent no. 2400506, Russian Federation (2010)

11. G.N. Jakunin, I.P. Prokop'ev, V.V. Burakov, Patent no. 102021, Russian Federation (2011)

12. V.A. Ryzhenkov, N.A. Loginova, A.I. Bychkov, Patent no. 133546, Russian Federation (2013)

13. A.D. Yakovlev, N.Z. Evtyukov, T.I. Gol'ts, Russian Coatings Journal, 9 (2011) (in Russian)

14. E.F. Itsko, Russian Coatings Journal, 5 (2004) (in Russian)

15. Y He, X Zhang, D Ph., and J Guan, Journal of Energy Engineering, 142, 4 (2016)

16. L Yuan, X. L. Weng, J. L. Xie, and L. J. Deng, Materials Research Innovations, 19, 1 (2015)

17. S.B. Prokhorov, L.F. Vagina, Stroitel'nye materialy [Construction materials], 6 (2006) (in Russian)

18. E.V. Grikshtas, Russian Coatings Journal, 9 (2005) (in Russian)

19. V.V. Verkholantsev, Vodnye kraski na osnove sinteticheskih polimerov [Water Paints Based on Synthetic Polymers] (Himija, Moscow, 1968) (in Russian)

20. E.A. Indeykin, L.N. Leibzon, I.A. Tolmachev, Pigmentirovanie lakokrasochnyh materialov [Pigmenting of paint and varnish coatings] (Himija, Moscow, 1986) (in Russian)

21. O.V. Orlova, T.N. Fomicheva, Tehnologija lakov i krasok [Paint and varnish technology] (Himija, Moscow, 1990) (in Russian)

22. E.E. Kazakova, O.N. Skorokhodova, Vodno-dispersionnye akrilovye lakokrasochnye materialy stroitel'nogo naznachenija [Water-dispersion acrylic paint and varnish coatings for construction purposes] (Paint-Media, Moscow, 2003) (in Russian) 